\title{
Experimental Study of Performance and Emissions of Fusel Oil-Diesel Blend in a Single Cylinder Diesel Engine
}

\author{
Omar I. Awad, Rizalman Mamat, Obed M. Ali, Mohd Fahmi Othman, and A. A. Abdullah
}

\begin{abstract}
In order to reduce the dependency on fossil oil energy resources, the using of several energy resources in compression-ignition engine has been the target of attention of researchers. The major renewable alternative combustible species are methanol, biogas, ethanol, biodiesel, and hydrogen. Fusel oil is a by-product of bioethanol production during the fermentation process present one of the new alternative fuels for compression-ignition engine. The aim of this work is to experimentally investigate the effect of fusel oil -diesel blending on performance and emission in single cylinder compression ignition engines. The test achieved under $25 \%$ engine load at five-engine speed 1200 to $2400 \mathrm{rpm}$ with intervals of $300 \mathrm{rpm}$. The experimental results revealed that the engine indicted power and torque slightly decrease for $F_{2} 0$ compared with pure diesel, and the increment was happened in fuel consumption. Although diesel fuel yields, the highest volumetric efficiency and exhaust temperature. Moreover, the results showed $\mathrm{CO}_{2}$ and CO were increased while the NOx emissions decrease with the use $F_{2} 0$. All the negative effects that happened in power and torque was because of the water content, low heating value, low cetane number for fusel oil.
\end{abstract}

Index Terms-Fusel oil, NOx emissions, single cylinder engine, alternative fuels, engine performance.

\section{INTRODUCTION}

Research on alternative renewable fuels has become quite important worldwide due to anxieties about the impacts of conventional fuel usage on global warming. Alternative fuels can be obtained from the renewable material such as waste agriculture and can offer decrease of conventional fuel consumption [1]. Current diesel engines demand a clean burning, stable fuel that performs well under a variety of operating conditions. The attention to utilizing renewable and alternative fuels in internal combustion has been accelerated recently according to a rapid decrease in crude oil reserves, growth in the costs of the fossil oil fuels and restrictions on exhaust emissions from internal combustion (IC) engines triggered by environmental concern. NOx emissions from the ignition combustion engine related with many reasons such as engine operating conditions and fuel properties. It is known that the thermal NOx emissions are linked to higher in-cylinder temperature and prompt NOx with $\mathrm{CH}$ of fuels. The idea of using alcohols as a means of producing cleaner diesel engines was introduced over 50 years ago. Also, there

Manuscript received December 14, 2015; revised March 1, 2016

Omar I. Awad is with Universiti Malaysia Pahang, Malaysia (e-mail: omaribr78@gmail.com).

Rizalman Mamat, Obed M. Ali, A. A. Abdullah, and Mohd Fahmi Othman are with Faculty of Mechanical Engineering, Universiti Malaysia Pahang, Malaysia (e-mail: rizalman@ump.edu.my, obedmajeed@ump.edu.my, adam@ump.edu.my). several studies achieved with alcohols as pure, blended and additive with diesel in compression-ignition (CI) engines with diesel [2]-[4] Important research that achieved with methanol-diesel and ethanol-diesel blends on the performance and emission of diesel engines.

Hulwan et al. [5] performed the test on direct injection (DI) diesel engine and blends of ethanol, diesel, and biodiesel. As results, the brake specific fuel consumption increased considerably, thermal efficiency enhanced slightly, smoke opacity decreased especially at high loads. NOx variation released with operating conditions while carbon dioxide $\mathrm{CO}$ emissions drastically raised at low loads

Jincheng, et al. [4]. The used various amount of ethanol blending with diesel and they study the effect of this fuels on performance and emission of a diesel engine. As a result, the torque, power, and thermal efficiencies decreased as well the NOx emission decreased. While the $\mathrm{CO}$ and $\mathrm{HC}$ increased compared with diesel.

Fusel oil is a by-product of alcohol production with fermentation through the distillation process and [7]-[9]. Fusel oil has the appearance of an alternative fuel for use in a spark ignition engine, The composition and amount of the fusel oil depends on the type of carbon used in the alcohol production, fermentation process, preparation method, and decomposition method of the fusel oil in the mixture [10]. The use of fusel oil as an alternative fuel may be accepted as a new energy source in diesel engines. However, the study of using fusel oil with diesel is not be found in literature but there are limited studies achieved with gasoline in spark ignition engine. In this study that achieved on single cylinder, diesel engine with five different speed and half load $25 \%$, was used to determine the influence of the blends of fusel oil-diesel $\mathrm{F}_{2} \mathrm{O}$ on engine performance, emission and compared with pure diesel. The effects of test fuels on, engine power, torque, specific fuel consumption, exhaust temperature, In-cylinder pressure ,thermal efficient emissions were examined.

TABLE I: THE PROPERTIES OF TEST FUELS

\begin{tabular}{llll}
\hline \hline fuel properties & Diesel & Fusel oil & $\mathrm{F}_{2} \mathrm{O}$ \\
\hline \hline Density $[\mathrm{kg} / \mathrm{m} 3]$ & 746 & 847 & 761 \\
higher heating value & 47.5 & 30 & 42.12 \\
MJ/kg & & & \\
Cetane Number & 46 & - & 38 \\
Water content \% & - & 13.5 & 0.88 \\
\hline \hline
\end{tabular}

\section{EXPERIMENTAL SET-UP}

This study has been conducted at single cylinder diesel engine YANMAR TF120 with $0.63 \mathrm{~L}$ and 17.7 Compression ratio with Hydrome model HGP-3A-F23 dynamometer. The 
exhaust gas analyzer also included in the engine test bed and the specification and valve timing of the engine is tabulated in Table II and Table III. The schematic diagram of the engine test bed is shown in Fig. 1.The data was collected by TFX Engineering, which consists of the in-cylinder pressure sensor, and crank angle sensor was used to collect data during the engine testing. The parameter outputs that produced were engine power, torque, in-cylinder pressure, exhaust temperature and maximum combustion temperature. The temperature measured by a K-type thermocouple and the temperature readings were displayed via data logger. By using this device, the temperatures that can be measured are including intake temperature, exhaust temperature, and ambient temperature. The experimental contacted with five speeds from $1200 \mathrm{rpm}$ to $2400 \mathrm{rpm}$ with intervals of $300 \mathrm{rpm}$ and engine load $25 \%$. The test achieved with pour diesel F0 and fusel oil diesel blend $\mathrm{F}_{2} \mathrm{O}(20 \%$ vol fusel oil and $80 \%$ vol diesel ). The properties of $\mathrm{F}_{2} \mathrm{O}$ and $\mathrm{F} 100$ (fusel oil ) shown in Table I have been measured at the chemical laboratory of UMP. The tests achieved under steady state conditions and first started with pure diesel to get the base data of the engine. The engine power, torque, fuel consumption (FC), exhaust temperature, volumetric efficiency and emissions $\left(\mathrm{CO}_{2}, \mathrm{CO}\right.$ and NOx) have been measured in the experiment.

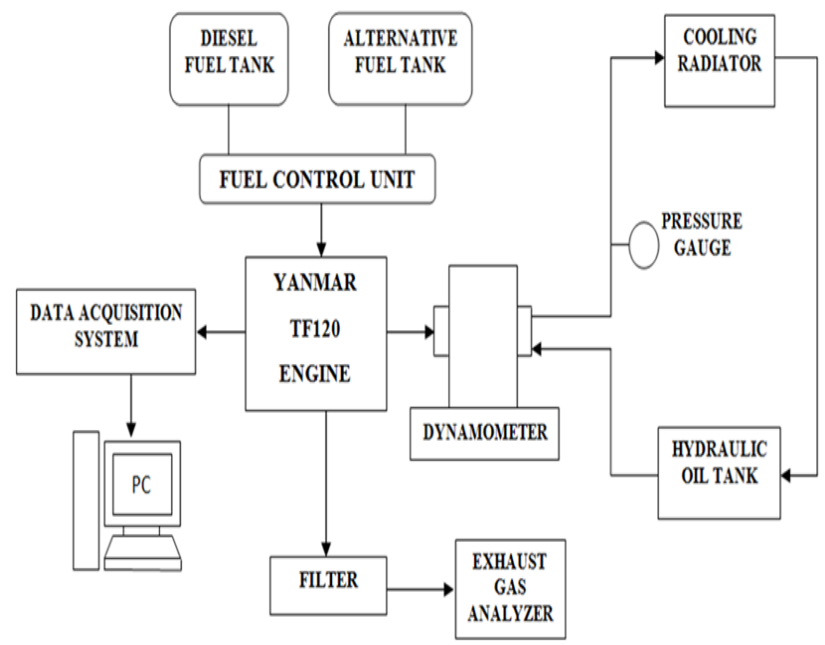

Fig. 1. Schematic view of experimental setup of Yanmar TF 120.

TABLE П: VALVE TIMING

\begin{tabular}{ll}
\hline \hline Position & Crank angle degree $\left(^{\circ}\right)$ \\
\hline \hline Intake valve opens BTDC & 6 \\
Intake valve closed ABDC & 35 \\
Exhaust valve opens BBDC & 38 \\
Exhaust valve closed ATDC & 7 \\
\hline \hline
\end{tabular}

\section{RESULTS AND DISCUSSION}

As mentioned above, the study tests were achieved on in single cylinder engine using pure diesel F0 (100\%vol diesel ) and $\mathrm{F}_{2} 0(80 \% \mathrm{vol}$ diesel and $20 \% \mathrm{vol}$ fusel oil $)$. The engine power, speeds, torques, fuel consumptions and volumetric efficiency were measured. The engine emissions $(\mathrm{CO}),\left(\mathrm{CO}_{2}\right)$, (NOx) emissions, engine temperature and In -cylinder pressure were analyzed. The results are shown as follow.

TABLE III: ENGINE SPECIFICATION

\begin{tabular}{ll}
\hline \multicolumn{1}{c}{ TABLE III: ENGINE SPECIFICATION } \\
\hline \hline Description & Specification \\
\hline Engine model & YANMAR TF120 \\
Engine type & Horizontal, diesel 4 stroke cycle \\
Combustion system & Direct injection \\
Number of cylinders & 1 \\
Bore $\times$ Stroke (mm) & $92 \times 96$ \\
Displacement (L) & 0.638 \\
& Length: 776 \\
Dimensions (mm) & Width: 379.5 \\
& Height: 621 \\
Injection timing & $17^{\circ}$ BTDC \\
Fuel injection pump & Bosch \\
Injection pressure $\left(\mathrm{kg} / \mathrm{cm}^{2}\right)$ & 200 \\
Compression ratio & 17.7 \\
\hline \hline
\end{tabular}

\section{A. In-Cylinder Pressure and Performance}

Fig. 2 shows the different in-cylinder pressures for fusel oil $\mathrm{F}_{2} \mathrm{O}$ and diesel $\mathrm{F} 0$ at $25 \%$ engine load through five-speed 1200 to 2400 with intervals of $300 \mathrm{rpm}$. All engine performance and emission especially thermal nitrogen oxide (NOx) related with in-cylinder pressure. The Fig. 2 present 10 in-cylinder pressure cycles plotted by $3 \mathrm{D}$ besides all the first cycle presents fusel oil $\left(\mathrm{F}_{2} \mathrm{O}\right)$ and another one present pure diesel. At almost the pressure of diesel slightly higher than $\mathrm{F}_{2} 0$.

The difference of engine torque and power depending on using of fusel oil-diesel blend and pure diesel at five engine speeds and 25\% engine load are described in Fig. 3 and 4 . The engine power and torque have increased at all engine speeds. Despite the low heating value of $\mathrm{F}_{2} \mathrm{O}$ proportion to diesel, it has seen that the torque and power have slightly decreased with pure diesel(F0).The similar results of decreased power and torque were achieved by using biodiesel [6], [7] and ethanol [8]. The oxygen content of fusel oil represents one of the main reason to improve the in-cylinder combustion reactions, despite the higher water content $(13.5 \%)$ of fusel oil and lower heating value. Also the water content one of the reasons that lead to worse combustion and increased the heat loss Thereby. As a result the power and torque decreased [9]. The maximum engine power and torques have measured at $2400 \mathrm{rpm}$ were $5.3 \mathrm{kw}$ and $21.5 \mathrm{Nm}$ for $\mathrm{F}_{2} \mathrm{O}$ and $\mathrm{F}_{2} \mathrm{O}$ respectively. 


\section{In cylinder pressure for F20 and Diesel} at different speeds and $25 \%$ load

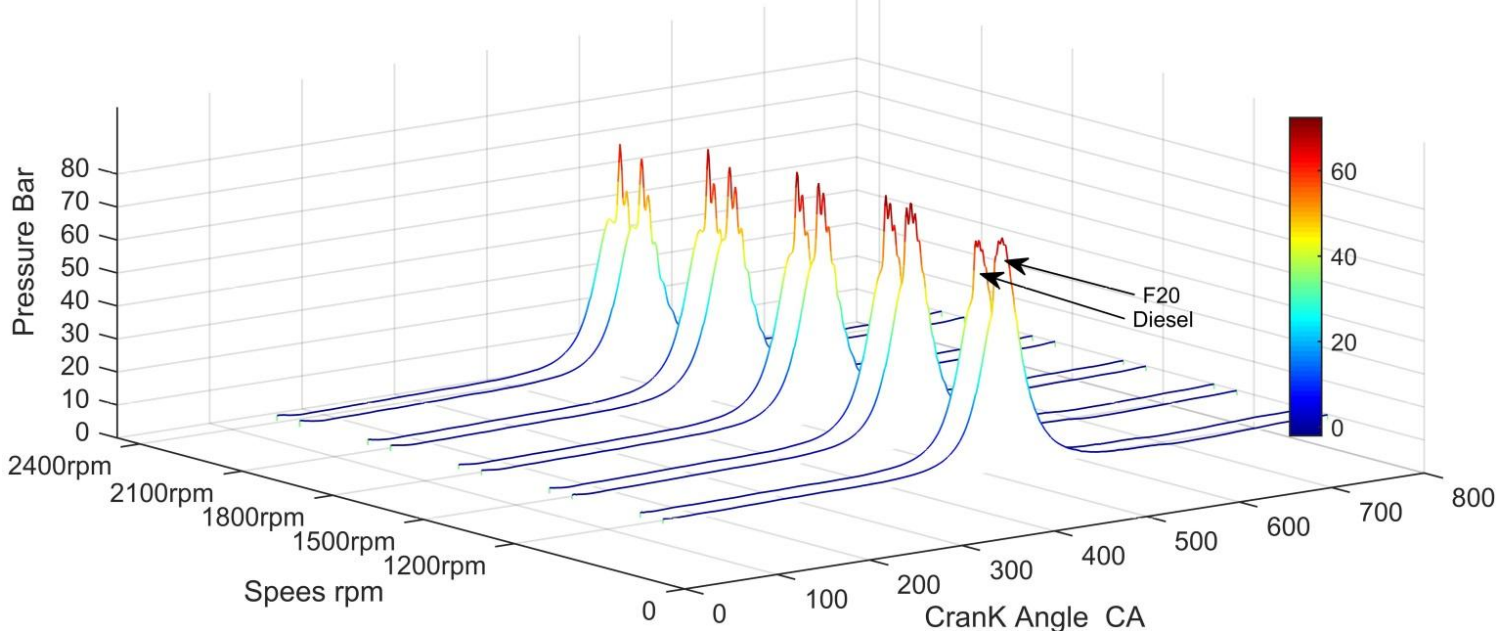

Fig. 2. Differences in cylinder pressure for $\mathrm{F}_{2} 0$ and Diesel at five engine speeds.

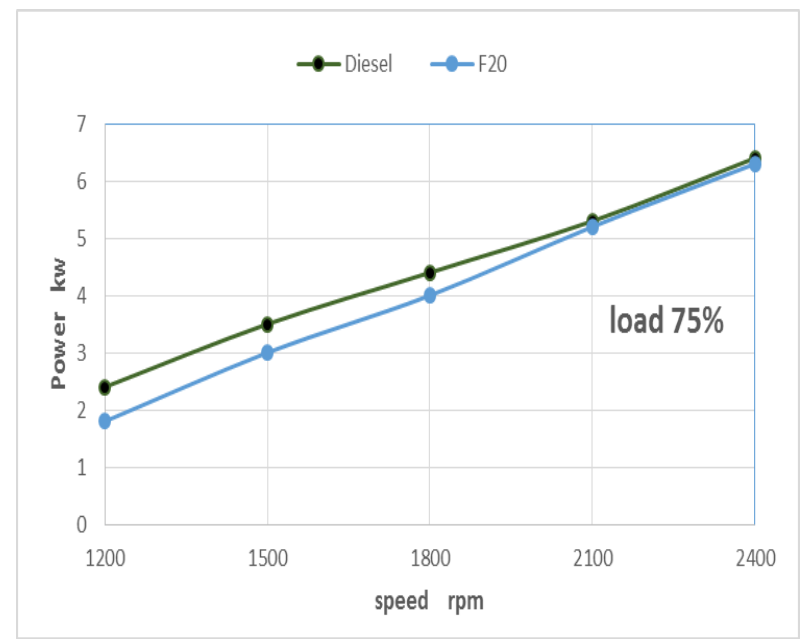

Fig. 3. Comparison power for diesel and $\mathrm{F}_{2} \mathrm{O}$.

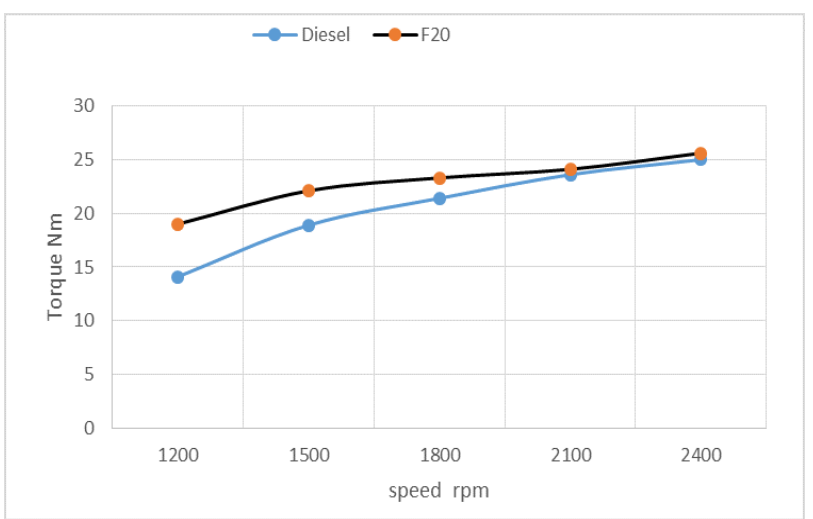

Fig. 4. Comparison torque for diesel and $\mathrm{F}_{2} \mathrm{O}$.

\section{B. Volumetric Efficiency and Fuel Consumption}

During the engine speed increases, the energy driven into the cylinder increases. The low heating value of fusel oil (30 $\mathrm{MJ} / \mathrm{Kg}$ ) compared to pure diesel (F0) $(47.5 \mathrm{MJ} / \mathrm{Kg})$ led to decreased the heating value of fuel test $\left(\mathrm{F}_{2} \mathrm{O}\right)$ as shown in Table I. Despite the low heating value of $\mathrm{F}_{2} \mathrm{O}$ proportion to diesel, it has seen that the torque and power have slightly decreased with pure diesel (F0). The difference of volumetric efficiency and fuel consumption of $\mathrm{F}_{2} \mathrm{O}$ and pure diesel at five engine speeds and 25\% engine load are shown in Fig. 5 and 6. At all speeds, the volumetric efficiency of $\mathrm{F}_{2} \mathrm{O}$ higher than diesel thereby that lead to explain the increase in fuel consumption. Furthermore, the latent heat of evaporation of alcohol based fuels is higher than diesel that permits lower manifold temperatures and higher volumetric efficiency [10], [11]. The heating value of fusel oil results in raised fuel consumption but the thermal efficiency is not affected significantly.

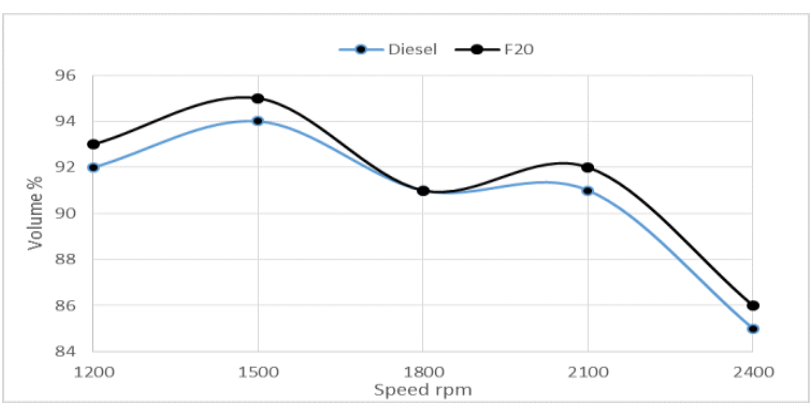

Fig. 5. Comparison volumetric efficiency for diesel and $\mathrm{F}_{2} 0$.

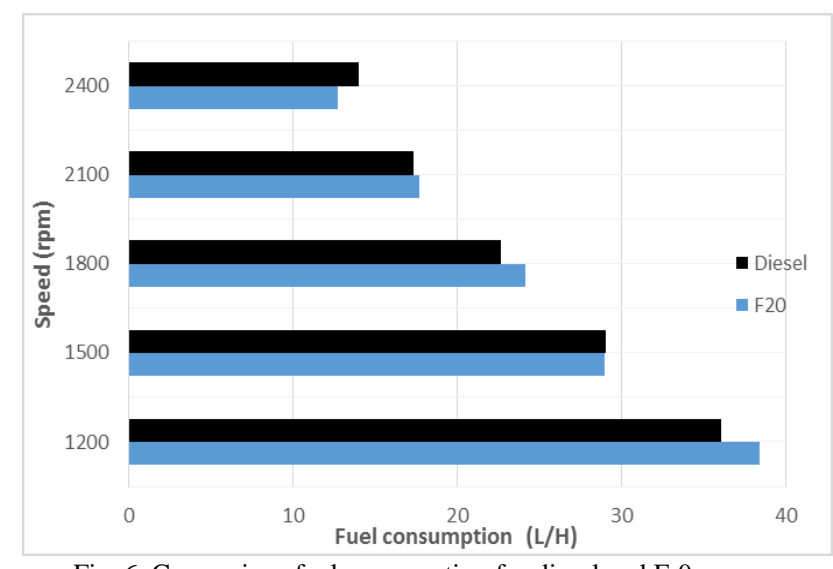

Fig. 6. Comparison fuel consumption for diesel and $\mathrm{F}_{2} 0$.

\section{Emissionand Exhaust Temperature.}

The variation of exhaust temperature with different engine speeds for $\mathrm{F}_{2} \mathrm{O}$ and diesel F0 is presented in Fig. 7. Besides all the first cycle presents the in-cylinder temperature for fuel oil $\left(\mathrm{F}_{2} \mathrm{O}\right)$ and another one present pure diesel. At almost the temperature of diesel slightly higher, than $\mathrm{F}_{2} 0$.Furthermore, the maximum temperature measured at $2400 \mathrm{rpm}$ for diesel, which was $340 \mathrm{C}$ while for $\mathrm{F}_{2} 0$, was 300 at the same speed. The high oxygen content of fusel oil must lead to the higher 
in-cylinder temperature in the combustion chamber according to its higher latent heat of evaporation, but the high water content caused worse combustion, which results in less torque, and power compared diesel fuel

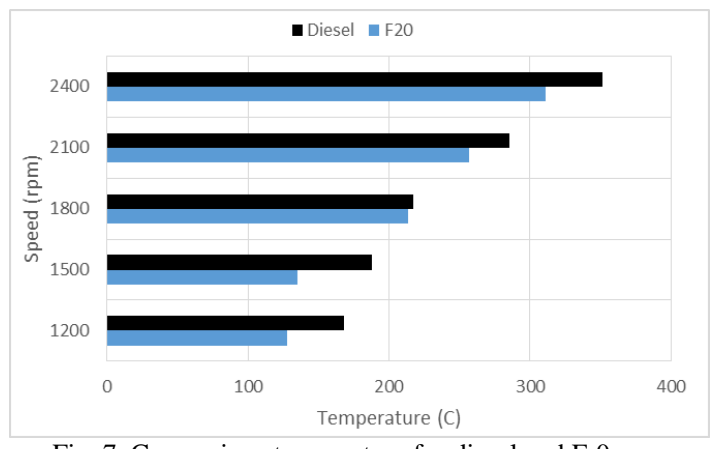

Fig. 7. Comparison temperature for diesel and $\mathrm{F}_{2} 0$.

\section{Engine Emissions}

The influences of fusel oil on emissions vary related with engine operating conditions. NOx is the greatest harmful gaseous emission from a compression ignition engine. NOx formation highly related on the combustion temperature and all engine-operating conditions influence the formation of NOx such as engine speed and engine load. NOx formation happens at temperatures above $1500 \mathrm{C}$, and the rate of the formation increases quickly with increasing temperature above 1500c [12]-[15]. NOx emissions decrease with using fusel oil compared with diesel as shown in Fig. 8. The oxygen content in the fuel oil and alcohols, which leads to a more complete and cleaner combustion[16]. Also, the higher oxygen content in the mixture promotes the $\mathrm{NOx}$ formation [17], [18]. As a result, the NOx decreased with $\mathrm{F}_{2} 0$ compared with pure diesel.

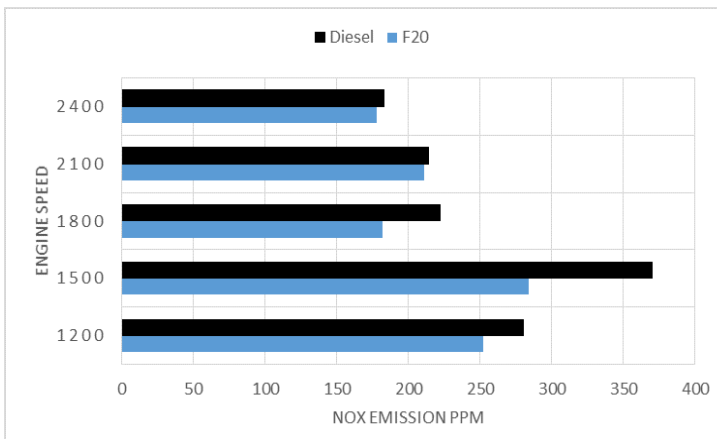

Fig. 8. Comparison NOx for diesel and $\mathrm{F}_{2} 0$.

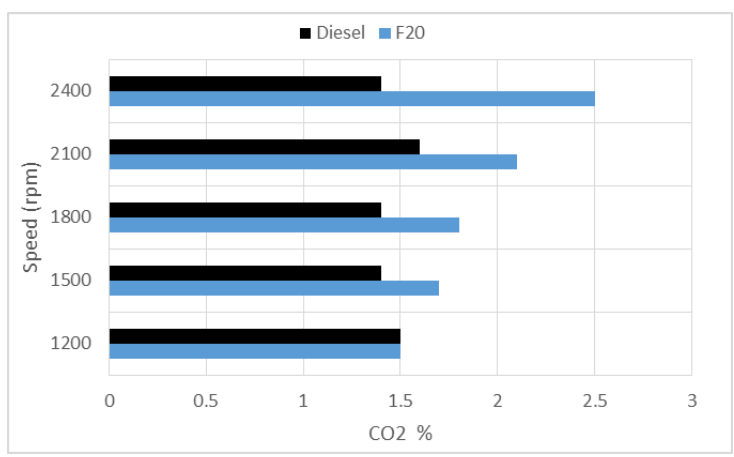

Fig. 9. Comparison $\mathrm{CO}_{2}$ for diesel and $\mathrm{F}_{2} \mathrm{O}$.

Fig. 9 and 10 illustrated the $\mathrm{CO}_{2}$ and $\mathrm{CO}$ emission for $\mathrm{F}_{2} \mathrm{O}$ and pure diesel at different engine speeds. As results, $\mathrm{CO}_{2}$ and $\mathrm{CO}$ emission increased with $\mathrm{F}_{2} 0$. The main reason for the high the $\mathrm{CO}_{2}$ and $\mathrm{CO}$ emission is due to the high oxygen content of fusel oil.

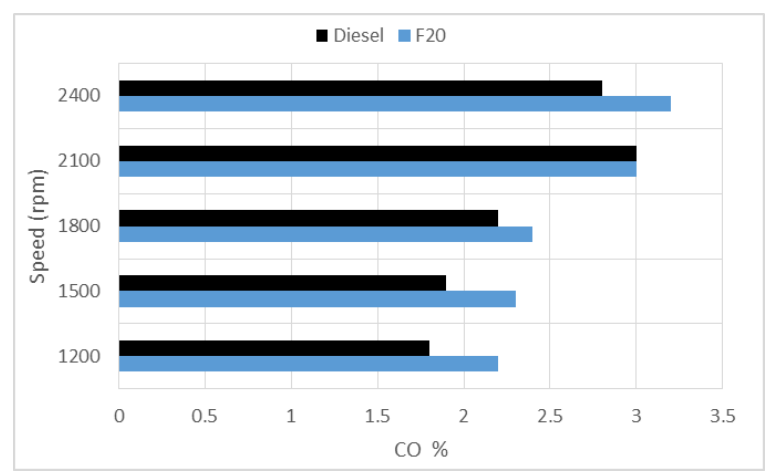

Fig. 10. Comparison $\mathrm{CO}$ for diesel and $\mathrm{F}_{2} 0$.

\section{CONCLUSION}

The variations in the engine emission of a diesel engine using fusel oil--diesel and pure diesel were investigated. The blends containing 20-vol percentage fusel oil and 80-vol percentage diesel were prepared and tested in a diesel engine with different engine speeds and $25 \%$ load. Considering the experimental results, it is possible to draw following conclusions.

- The engine torque and power slightly decreased due the lower in-cylinder pressure for $\mathrm{F}_{2} \mathrm{O}$.

- The heating value of fusel oil results in raised fuel consumption but the thermal efficiency is not affected significantly.

- Due the low heating value and higher latent heat of evaporation of fusel oil the volumetric efficiency increased with $\mathrm{F}_{2} 0$.

- Due the high water content of fusel oil, the in-cylinder temperature slightly decreased.

- As compared to neat diesel and the $\mathrm{F}_{2} \mathrm{O}$ showed a drastic reduction on NOx emission.

- The $\mathrm{CO}_{2}$ and $\mathrm{CO}$ emission increased for $\mathrm{F}_{2} \mathrm{O}$ compared with pure diesel at all engine speeds.

\section{REFERENCES}

[1] A. Tsolakis, A. Megaritis, M. L. Wyszynski, and K. Theinnoi, "Engine performance and emissions of a diesel engine operating on diesel-RME (rapeseed methyl ester) blends with EGR (exhaust gas recirculation),' Energy, vol. 32, pp. 2072-2080, 2007.

[2] J. Kisenyi, C. Savage, and A. Simmonds, "The impact of oxygenates on exhaust emissions of six European cars," SAE Technical Paper 0148-7191, 1994.

[3] A. K. Agarwal, "Biofuels (alcohols and biodiesel) applications as fuels for internal combustion engines," Progress in Energy and Combustion Science, vol. 33, pp. 233-271, 2007.

[4] H. Bayraktar, "An experimental study on the performance parameter of an experimental CI engine fueled with diesel-methanol-dodecanol blends," Fuel, vol. 87, pp. 158-164, 2008.

[5] D. B. Hulwan and S. V. Joshi, "Performance, emission and combustion characteristic of a multicylinder DI diesel engine running on diesel-ethanol-biodiesel blends of high ethanol content," Applied Energy, vol. 88, pp. 5042-5055, 2011.

[6] J. Xue, T. E. Grift, and A. C. Hansen, "Effect of biodiesel on engine performances and emissions," Renewable and Sustainable Energy Reviews, vol. 15, pp. 1098-1116, 2011.

[7] S. Murillo, J. L. Míguez, J. Porteiro, E. Granada, and J. C. Morán, "Performance and exhaust emissions in the use of biodiesel in outboard diesel engines," Fuel, vol. 86, pp. 1765-1771, 2007. 
[8] M. Abu-Qudais, O. Haddad, and M. Qudaisat, "The effect of alcohol fumigation on diesel engine performance and emissions," Energy Conversion and Management, vol. 41, pp. 389-399, 2000.

[9] A. Calam, Y. İçingür, H. Solmaz, and H. Yamık, "A comparison of engine performance and the emission of fusel oil and gasoline mixtures at different ignition timings," International Journal of Green Energy, vol. 12, pp. 767-772, 2015.

[10] H. S. Yücesu, T. Topgül, C. Cinar, and M. Okur, "Effect of ethanol-gasoline blends on engine performance and exhaust emissions in different compression ratios," Applied Thermal Engineering, vol. 26, pp. 2272-2278, 2006.

[11] A. Bilgin, O. Durgun, and Z. Sahin, "The effects of diesel-ethanol blends on diesel engine performance," Energy sources, vol. 24, pp. 431-440, 2002.

[12] S. K. Hoekman and C. Robbins, "Review of the effects of biodiesel on NOx emissions," Fuel Processing Technology, vol. 96, pp. 237-249, 2012.

[13] S. Fernando, C. Hall, and S. Jha, "NO x reduction from biodiesel fuels, " Energy \& Fuels, vol. 20, pp. 376-382, 2006

[14] J. Sun, J. A. Caton, and T. J. Jacobs, "Oxides of nitrogen emissions from biodiesel-fuelled diesel engines," Progress in Energy and Combustion Science, vol. 36, pp. 677-695, 2010.

[15] B. R. Moser, A. Williams, M. J. Haas, and R. L. McCormick, "Exhaust emissions and fuel properties of partially hydrogenated soybean oil methyl esters blended with ultra low sulfur diesel fuel," Fuel Processing Technology, vol. 90, pp. 1122-1128, 2009.

[16] M. Mittelbach and C. Remschmidt, Biodiesel: The Comprehensive Handbook, Martin Mittelbach, 2004.

[17] H. Solmaz and İ. Celikten, "Estimation of number of vehicles and amount of pollutants generated by vehicles in turkey until 2030," Gazi University Journal of Science, vol. 25, pp. 495-503, 2012.

[18] E. Yilmaz, H. Solmaz, S. Polat, and M. Altin, "Effect of the three-phase diesel emulsion fuels on engine performance and exhaust emissions," Journal of the Faculty of Engineering and Architecture of Gazi University, vol. 28, pp. 127-134, 2013.

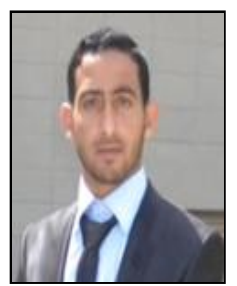

Omar I. Awad is a Ph.D. candidate of first year in mechanical engineering from Universiti Malaysia Pahang. He received his BSc. in refrigeration and air-conditioning engineering from College of Technology Kirkuk Iraq in 2010 and a master degree in energy from Dokuz Eylül Üniversitesi Turkey in 2015. He was born on December 21, 1987 in Iraq. His research interests are alternative fuel. He is conducting the research by using fusel oil with diesel.

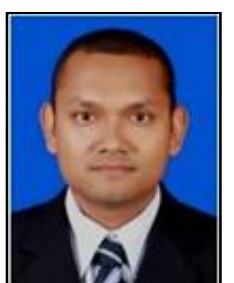

Rizalman Bin Mamat received his BSc and a master in mechanical engineering (aeronautics), Universiti Teknologi Malaysia and he obtained his $\mathrm{PhD}$ in fuel and energy from University of Birmingham, United Kingdom. Also, he is an associate professor at Faculty of Mechanical Engineering, Universiti Malaysia Pahang.

He was born in Malaysia. And he is a dean at Faculty of Mechanical Engineering, Universiti Malaysia Pahang, Date of appointment: 1 March 2015 $(1 / 3 / 15-28 / 2 / 17)$. Also he was the head of Focus Group, Energy Sustainability Focus Group. His research interests are in internal combustion engine, alternative energy, rocket propulsion system, fluid dynamics.
Dr. Rizalman Mamat was granted gold medal, Nano fluid technology, 23rd international invention, innovation \& technology also he got gold medal, development of high temperature combustor system for Automotive Casting Industries, Innovation and Invention Exhibition (InEx 2011), 6-7 December 2011 Exhibition, 17-19 May 2012, Kuala Lumpur.

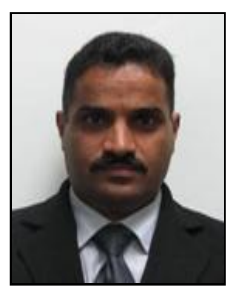

Obed Majeed Ali is a senior lecturer at the Faculty of Mechanical Engineering, University Malaysia Pahang. He obtained his BS (hon) and a MS from the Department of Mechanical Engineering / College of Engineering at Mosul University in 2000 and 2002, respectively, and a $\mathrm{PhD}$ in alternative fuel (biodiesel fuel) from the Faculty of Mechanical Engineering, Universiti Malaysia Pahang, Malaysia in 2014. Dr. Obed has worked as a lecturer in the Iraqi Foundation of Technical Institutions for about ten years before he continue his $\mathrm{PhD}$ study. His specialized areas are investigating blended biodiesel-diesel fuel property with chemical additives as a fuel for diesel engines and characterization of fuel combustion and engine cyclic variation. He is a member of The Iraqi Engineers Society.

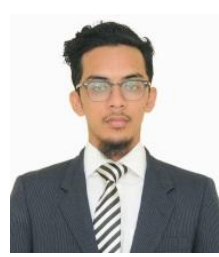

Mohd Fahmi Othman received his Bsc and a master in mechanical engineering from University Tun Hussein Onn Malaysia. Now he persuading his $\mathrm{Ph} . \mathrm{D}$ also in mechanical engineering at University Malaysia Pahang. His research interests are alternative fuel. He is conducting the research by using organic compound with diesel).

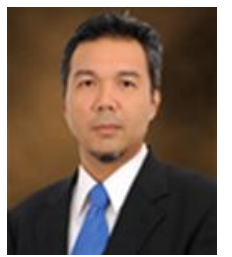

Abdul Adam Abdullah is a senior lecturer at the Faculty of Mechanical Engineering, University Malaysia Pahang. He obtained his PhD in ecosystem engineering (diesel spray and combustion) from Graduate School of Advanced Technology and Science, Tokushima University, Japan. His specialized areas are analyzing characteristic of diesel fuel spray and alternative fuel spray injected into diesel engine or optical accessible chamber. $\mathrm{He}$ is the member of professional body such as Society of Automotive Engineers (SAE), Japan Society of Automotive Engineers (JSAE) and The Japan Society of Mechanical Engineers (JSME). 